(h) To forward the recommendations of the preliminary investigation (undertaken by a committee of the Inter-University Committee on African Studies, see Bantu Studies, Volume VII, No. r), and to make further recommendations for the development of literature and language study.

(i) To award distinction to any one publication in any one year.

Meanwhile opinion and advice are being widely sought (I) upon the principle of establishing at the present time such Academies, and (2) regarding the composition of a representative Central Bantu Literature Committee. The work of this Committee would be :

(a) To decide on the number of Academies to be set up, and the details of their functions.

(b) To appoint the foundation members of each Academy.

(c) To receive reports from the Academies, to co-ordinate their operations, to confirm their proposals, and to decide upon general principles for their guidance.

(d) To confirm the election of additional members to Academies.

(e) To undertake the raising of funds to assist in financing publications recommended by the Academies.

(f) To appoint standing sub-committees on (i) publications, (ii) educational literature, (iii) translations, etc.

(g) To act in consultation with the Inter-University Committee for African Studies and other such bodies.

\title{
Dr. I. C. Ward's Linguistic Tour in SE. Nigeria.
}

In my five and a half months' stay in S. Nigeria, which was made possible by the Rockefeller Grant to the School of Oriental Studies, London, two main aims were before me, (I) to verify and supplement the work done in England on Efik and to collect material for a short comparative study of the Ibibio-Efik group of languages and some of its main dialects; (2) to begin work on the tones of Ibo and their function, and to gather information about the main dialects of this difficult language. In addition to these two objects, having had thirteen years' experience of teaching English to foreigners, I was interested in the teaching of English, particularly the spoken language, and found time to make observations on this aspect of language work and to lecture on it in several centres.

My plans had been discussed beforehand with the Director of Education for Nigeria, Mr. E. R. J. Hussey, and I am indebted to him and his staff, particularly to Mr. R. F. G. Adams who is in charge of the Ibo and Efik Translation Bureaux, to District Officers and to the Scottish, Methodist, Qua Iboe and Church Missionary Societies for the excellent arrangements for my work and the smooth working of my plans and for frequent hospitality 
on my travels. I should like to put on record my thanks for the kindness I received, and especially for the appreciation and welcome that was given to the work I was undertaking.

Ibibio-Efik. I spent three weeks in Calabar working on Efik, where there was opportunity of testing the work already done, with a considerable number of Efik speakers from the Hope Waddell Institution and from various schools in the town, and I was able to visit schools and hear Efik reading carried on. I also had the opportunity of meeting the Efik Literature Committee which consists of Europeans and Africans. I lectured on Efik and its tonal structure and on English pronunciation to a large audience of teachers, and considerable interest was shown in the particular aspects of both languages on which I concentrated.

I spent three weeks collecting data in Ibibio, Oron, Eket, Anay and Ibeno, staying for this purpose at Oyubia (Oron district) Itam, Itu and Ikotekpene. The Short Guide for the Recording of African Languages proved most useful and I was able to fill it in fully for most of these dialects. I am at pregent engaged on making a comparison of them and hope to be able to publish my results shortly. Here I may say that my general impression is that they differ most in vocabulary, to a less extent in their sound system and grammar, and very little in tones. I found Efik understood by all educated speakers.

Ibo. For this work I made my head-quarters at Umuahia in the Bende division, where a bungalow at the Government College was put at my disposal. From here I travelled to Enugu, Awka, Onitsha, Asaba, Owerri, Aba and collected material (the Guide, stories and texts and much grammatical matter) in the Abo, Agbor, Afikpo, Agbaja, Asaba, Arochuku, Bonny, Kwale, Ngwa, Onitsha and Owerri dialects.

There are many questions with regard to the Ibo language which are difficult to solve, and I do not pretend to have done more than make a beginning of collecting data upon which decisions may be made: the many and widely varying dialects, which is most suitable to be used as a literary medium, the place of 'Union Ibo', the development of a 'Spoken Union' consisting of a kind of 'common denomination' of the main dialects which seems to be growing naturally, owing to increased intercourse and the movement of educated Ibos about the country. Apart from the question of dialects, Ibo is a difficult language with a wide vocabulary and considerable variety of constructions, in which tone plays a most important part. $U_{p}$ to the present, the function of tone, apart from mere semantic or etymological tone, has been little studied and I spent a large part of my time in collecting material out of which to ' dig' the rules of the Ibo tone usages; these are difficult to track and will not be easy to formulate. There is no doubt, however, that such tone rules exist.

In several places I lectured on Ibo and explained the purpose of my work, and had the opportunity of discussing it with Europeans, members of the 
Education and other Government services, missionaries of long experience and with educated Africans who showed themselves most interested in this - to them-new aspect of their language. I also met the Ibo Literature Committee, on which Africans were well represented. It is too early to say how my material can be used, but it ought in time to be possible to set out my findings, incomplete as they must be.

The question of the orthography of Efik and Ibo is, unhappily, not satisfactorily settled: the Government has authorized the use of the new script in its schools, and books are being produced in it, but the Missions who accepted it in 1929 have since decided not to use it. This is largely though not wholly due to financial reasons, the reprinting of the Bible in the new script being a proposition which no Mission can face at present. The division in the country on an important question of this kind is greatly to be regretted.

(Communicated by Dr. I. C. Ward.)

\section{African Research Survey.}

Readers of this journal will have noted with interest recent announcements in the press that a survey was to be made of the extent to which modern knowledge was being applied to the problems of Africa. For the last two years a group of persons interested in Africa have been considering the possibility of such a survey, as a prelude to further development of study and research, and to the wider application and better co-ordination of their results. Lord Lothian is the Chairman of the group and the other members include Lord Lugard, the Rt. Hon. W. Ormsby Gore, Mr. Lionel Curtis, Dr. Oldham, Sir Arthur Salter, Professor Julian Huxley, and Professor Coupland. It will be seen that the Chairman and Administrative Director of this Institute are associated with the inquiry. Through the generosity of the Carnegie Corporation, funds have been made available to meet the cost of the initial survey, and the services of Sir Malcolm Hailey, G.C.S.I., G.C.I.E., Governor of the United Provinces in India, have been secured, after his retirement next autumn, to carry out the inquiry and to prepare a report.

The aim of the survey is purely objective. Its purpose is to show the existing situation in study and research, to note fields in which little is being done, and to observe the degree to which knowledge is related and applied to the chief problems of the continent. During the current year a certain amount of preparatory work is being undertaken. Dr. E. B. Worthington, the Cambridge ecologist, who has already had experience of research in Africa, is preparing a preliminary report on the work which is being done in, or on account of, Africa in the field of natural and biological science. Specialist help is at the disposal of the group in collecting comparative material referring to other aspects of the inquiry, and in particular this 